\title{
Magnesium borohydride: A new hydrogen storage material
}

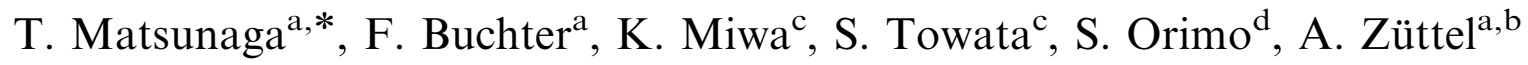 \\ ${ }^{a}$ Physics Department, University of Fribourg, Pérolles, 1700 Fribourg, Switzerland \\ ${ }^{\mathrm{b}}$ EMPA, Department Environment, Energy and Mobility, Abt. 138 “Hydrogen \& Energy", Überlandstrasse 129, 8600 Dübendorf, Switzerland \\ ${ }^{\mathrm{c}}$ Toyota Central R\&D Labs., Inc., Nagakute, Aichi 480-1192, Japan \\ ${ }^{\mathrm{d}}$ Institute for Materials Research, Tohoku University, Sendai 980-8577, Japan
}

\begin{abstract}
Magnesium borohydride $\left(\mathrm{Mg}\left(\mathrm{BH}_{4}\right)_{2}\right)$ is a promising material for hydrogen storage because of its high gravimetric storage density (15.0 mass\%). We intended to synthesize $\mathrm{Mg}\left(\mathrm{BH}_{4}\right)_{2}$ by decomposition reaction of $\mathrm{LiBH}_{4}$ with $\mathrm{MgCl}_{2}$ by heat treatment without using a solvent, where the product consists of $\mathrm{LiCl}$ and a compound of magnesium, boron and hydrogen. Hydrogen desorption temperature of the product is approximately $100 \mathrm{~K}$ lower than that of $\mathrm{LiBH}_{4}$ and the decomposition consists of a two-step reaction. The products of the 1st and 2nd decomposition reactions are $\mathrm{MgH}_{2}$ and $\mathrm{Mg}$, respectively. This result indicates the following two-step reaction (1st reaction: $\mathrm{Mg}\left(\mathrm{BH}_{4}\right)_{2} \rightarrow \mathrm{MgH}_{2}+2 \mathrm{~B}+3 \mathrm{H}_{2}$, 2nd reaction: $\left.\mathrm{MgH}_{2} \rightarrow \mathrm{Mg}+\mathrm{H}_{2}\right)$. The first decomposition peak is dominant and is around $563 \mathrm{~K}$. The 2nd decomposition occurs at the temperature greater than $590 \mathrm{~K}$.
\end{abstract}

Keywords: Hydrogen absorbing materials; Thermodynamic properties; Thermal analysis

\section{Introduction}

High-density hydrogen storage is one of the most important issues to introduce fuel cell vehicles. Complex hydrides, consisting of light elements, are very promising materials for hydrogen storage because of their high gravimetric and volumetric hydrogen density [1]. Since Bogdanovic and Schwickardi reported the reversibility of the catalyzed hydrogen sorption reaction of $\mathrm{NaAlH}_{4}$ [2], many efforts have been made to investigate complex hydrides as hydrogen storage materials [3-5]. Besides the basic physical properties, the challenges are to tailor the stability and to investigate the reversibility of the hydrogen sorption reaction of complex hydrides.

The hydrogen in the complex hydrides is often located in the corners of a tetrahedron with $\mathrm{B}$ or $\mathrm{Al}$ in the center. The negative charge of the anion, $\left[\mathrm{BH}_{4}\right]^{-}$and $\left[\mathrm{AlH}_{4}\right]^{-}$, is compensated by a cation, e.g. $\mathrm{Li}$ or $\mathrm{Na}$. Therefore, the bonding character and the properties of the complex hydrides are largely determined by the difference in

\footnotetext{
*Corresponding author.

E-mail address: tmatu@mvj.biglobe.ne.jp (T. Matsunaga).
}

electronegativity between the cation and the boron or aluminum. For example, the docomposition temperatures of complex hydrides consist of alkaline metal and $\left[\mathrm{BH}_{4}\right]^{-}$ or $\left[\mathrm{AlH}_{4}\right]^{-}$anion have a good correlation with electronegativity of cation as is shown in Fig. 1. Based on this correlation, experimental studies have been preformed to lower the stability of complex hydrides [6-8]. Also, theoretical calculations indicate that this tendency can be applied not only to alkaline metal borohydride, but also to other borohydrides with alkaline-earth metals or some of transition metals $[9,10]$.

Magnesium borohydride $\left(\mathrm{Mg}\left(\mathrm{BH}_{4}\right)_{2}\right)$ is one of the promising materials for hydrogen storage because of its high gravimetric storage density (15.0 mass \%). The Pauling electronegativity of magnesium is 1.31 , which is greater than that of lithium (0.98). This implies that $\mathrm{Mg}\left(\mathrm{BH}_{4}\right)_{2}$ is less stable than $\mathrm{LiBH}_{4}$. Until now, physical properties of $\mathrm{Mg}\left(\mathrm{BH}_{4}\right)_{2}$ as a hydrogen storage material are not known because it is difficult to synthesize the material. The process to synthesize $\mathrm{Mg}\left(\mathrm{BH}_{4}\right)_{2}$ has been mainly examined by two different approaches. One is the reaction of diborane $\left(\mathrm{B}_{2} \mathrm{H}_{6}\right)$ with magnesium or its compounds [11]. The other is the double decomposition of magnesium halides with 


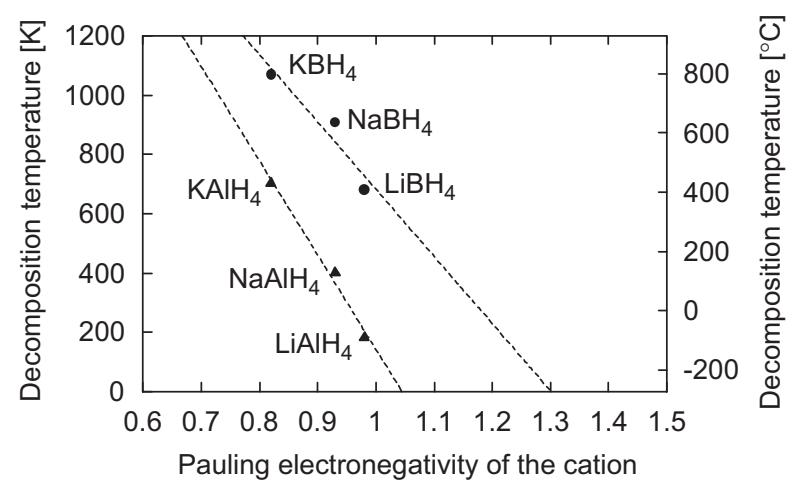

Fig. 1. Decomposition temperature as a function of Pauling electronegativity of the cation.

alkaline metal borohydrides in an organic solvent, e.g. diethyl ether or tetrahydrofuran [11,12]. The second approach has the advantage that it does not require diborane, which is a toxic compound. However, the product which is synthesized by double decomposition in a solvent is a solvate consisting of $\mathrm{Mg}\left(\mathrm{BH}_{4}\right)_{2}$ and solvent (e.g. $\left.\mathrm{Mg}\left(\mathrm{BH}_{4}\right)_{2} \cdot 3 \mathrm{THF}\right)$ and the extraction of $\mathrm{Mg}\left(\mathrm{BH}_{4}\right)_{2}$ from the solvate is difficult because of its affinity with the solvent [13].

In this study, we report about a new method intended to synthesize $\mathrm{Mg}\left(\mathrm{BH}_{4}\right)_{2}$ by dry process without using a solvent. Lithium borohydride and magnesium chloride are used as starting materials. The synthesis products as well as the hydrogen desorption products were investigated by X-ray diffraction and hydrogen desorption measurement of the product synthesized by the new method have been performed.

\section{Experimental}

The samples were purchased from Aldrich Co. Ltd.: the purities are $>95 \%$ for $\mathrm{LiBH}_{4},>99.9 \%$ for $\mathrm{MgCl}_{2}$, respectively. The samples were always handled in an argon glove box to avoid any possible reaction with moisture or air. The reaction between $\mathrm{LiBH}_{4}$ and $\mathrm{MgCl}_{2}$ was investigated by differential scanning calorimetry (DSC) (Mettler Toledo Inc. HP DSC827e). Five milligrams of the sample (for 2:1 mole ratio) was mixed in an argon glove box and filled in a DSC sample cell made of aluminum. The sample cell was sealed up in argon atmosphere. Therefore, it has never been exposed to any gases except pure argon during the measurement. DSC measurement of $\mathrm{LiBH}_{4}$ and $\mathrm{MgCl}_{2}$ mixture was carried out in the temperature range from 313 to $513 \mathrm{~K}$ at the heating (or cooling) rate of $5 \mathrm{~K} / \mathrm{min}$ in the sealed sample cell for three heating and cooling cycles. Measurements with pure $\mathrm{LiBH}_{4}$ and $\mathrm{MgCl}_{2}$ were also performed at the same heating condition.

Heat treatments of $\mathrm{LiBH}_{4}$ and $\mathrm{MgCl}_{2}$ mixture were carried out in a stainless steel cylinder $<10 \mathrm{MPa}$ of hydrogen at 453,523 or $593 \mathrm{~K}$. In each heat treatment, approximately $600 \mathrm{mg}$ of $\mathrm{LiBH}_{4}$ and $\mathrm{MgCl}_{2}$ mixture (for 2:1 mole ratio) was pressed in order to make a pellet and filled into a cylinder in an argon glove box. After evacuating by rotary vacuum pump for $1 \mathrm{~h}$ at room temperature, $10 \mathrm{MPa}$ of hydrogen was introduced into the cylinder and heated up. It was kept at the final temperature mentioned above for $3 \mathrm{~h}$ and then slowly cooled to room temperature.

Crystal structures of the samples were investigated at room temperature by powder X-ray diffraction measurement (SIEMENS, D-500, $\mathrm{Cu} \mathrm{K} \alpha$ ). To avoid exposure to air, each sample was filled into a sample holder in an argon glove box and covered with plastic wrap film during X-ray diffraction measurement.

Temperature-programmed desorption (TPD) measurement was carried out in vacuum continuously after heat treatment at $593 \mathrm{~K}$ in the same stainless steel cylinder. The desorbed gas volume was measured by a mass flow controller (Brooks instruments, $5850 \mathrm{E}$, max. flow 5 standard $\mathrm{cm}^{3} / \mathrm{min}$ ), with a maximum full-scale error of $1 \%$.

\section{Results and discussion}

The DSC profiles of $\mathrm{LiBH}_{4}$ and $\mathrm{MgCl}_{2}$ mixture are shown in Fig. 2. Profiles of pure $\mathrm{LiBH}_{4}$ and pure $\mathrm{MgCl}_{2}$ were also investigated as references. For $\mathrm{LiBH}_{4}$, there is an endothermic peak (at $T=386 \mathrm{~K}, \Delta Q=-206.0 \mathrm{~J} / \mathrm{g}$ ) during heating from 313 to $513 \mathrm{~K}$ and an exothermic peak during cooling both of them are corresponding to the phase transition of $\mathrm{LiBH}_{4}$, whereas no peak was observed for $\mathrm{MgCl}_{2}$ in this temperature range. For the $\mathrm{LiBH}_{4}$ and $\mathrm{MgCl}_{2}$ mixture sample, there is an endothermic peak (at $T=385 \mathrm{~K}, \Delta Q=-56.3 \mathrm{~J} / \mathrm{g}$ ) during the 1 st heating procedure, corresponding to the phase transition of $\mathrm{LiBH}_{4}$. However, this peak disappears after the cooling of 1 st cycle. This result indicates that there is no pure $\mathrm{LiBH}_{4}$ remains after the 1st heating. In addition, for the $\mathrm{LiBH}_{4}$ and $\mathrm{MgCl}_{2}$ mixture, other exothermic and endothermic peaks are observed after the 1 st cooling at $T=440 \mathrm{~K}$ $(\Delta Q=23.6 \mathrm{~J} / \mathrm{g})$. These peaks are not observed for pure $\mathrm{LiBH}_{4}$ or pure $\mathrm{MgCl}_{2}$. This result implies that some reaction took place during the 1 st heating. The endothermic peak at $440 \mathrm{~K}$ observed after the 1 st cooling is in agreement with the DSC measurement result which Stasinevich and Egorenko has reported for $\mathrm{Mg}\left(\mathrm{BH}_{4}\right)_{2}$ [14]. Therefore, the following reaction during the $1 \mathrm{st}$ heating procedure is assumed:

$2 \mathrm{LiBH}_{4}+\mathrm{MgCl}_{2} \rightarrow \mathrm{Mg}\left(\mathrm{BH}_{4}\right)_{2}+2 \mathrm{LiCl}$.

XRD measurement results after heat treatment also indicate that $\mathrm{LiBH}_{4}$ react with $\mathrm{MgCl}_{2}$ during heat treatment. Fig. 3 shows the XRD measurement results after heat treatment at various temperatures. Simply mixing $\mathrm{LiBH}_{4}$ and $\mathrm{MgCl}_{2}$ in an inert atmosphere (Ar) does not lead to any reaction. However, after heat treatment, the peaks corresponding to $\mathrm{LiBH}_{4}$ and $\mathrm{MgCl}_{2}$ disappear. New peaks were observed which correspond to LiCl. Although there is still a small amount of $\mathrm{LiBH}_{4}$ and $\mathrm{MgCl}_{2}$ after heat treatment at $453 \mathrm{~K}$, neither $\mathrm{LiBH}_{4}$ nor $\mathrm{MgCl}_{2}$ was observed after heat treatment at the 


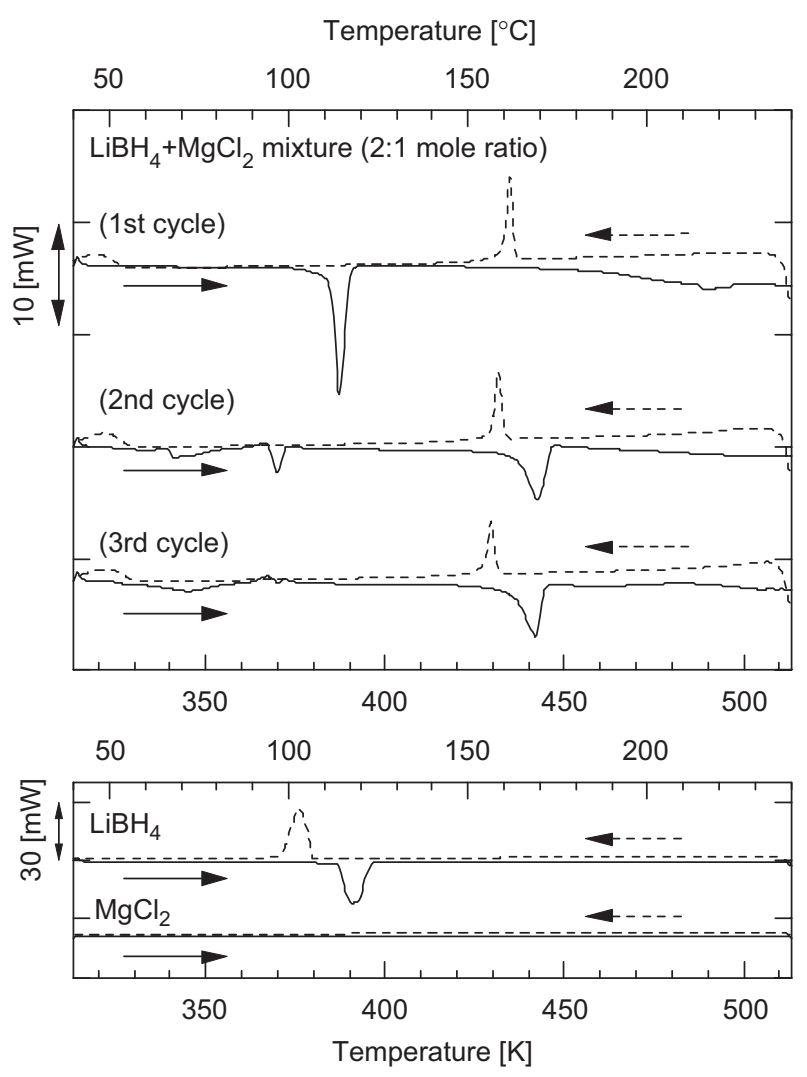

Fig. 2. Differential scanning calorimetry profiles of $\mathrm{LiBH}_{4}$ and $\mathrm{MgCl}_{2}$ mixture with a sealed sample cell. The heating rate is $5 \mathrm{~K} / \mathrm{min}$. Measurements with pure $\mathrm{LiBH}_{4}$ and $\mathrm{MgCl}_{2}$ were also performed at the same heating condition. Solid lines and dotted lines show heating and cooling, respectively. Five milligrams of the sample was used for each measurement.

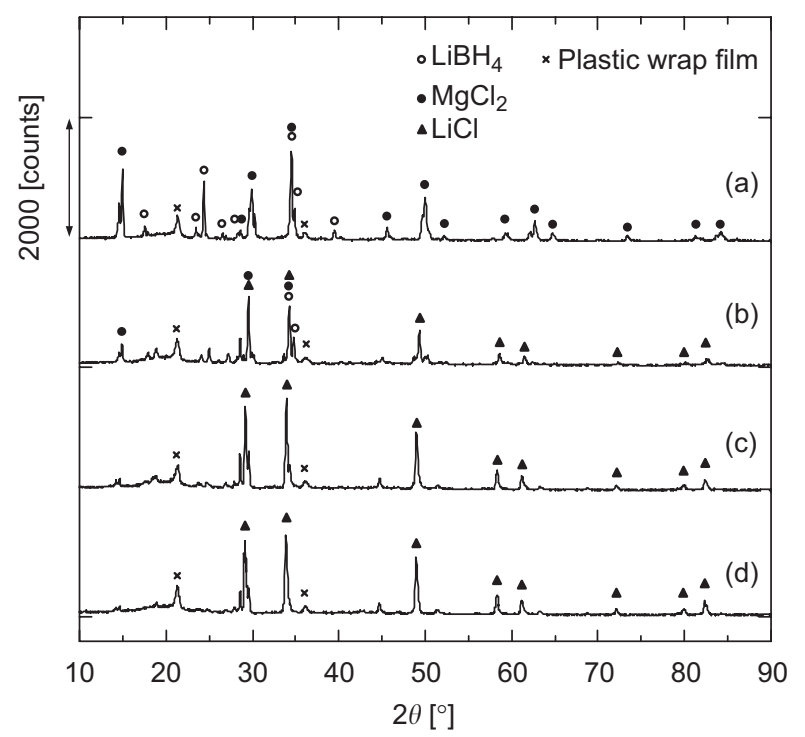

Fig. 3. Powder X-ray diffraction profiles of $\mathrm{LiBH}_{4}$ and $\mathrm{MgCl}_{2}$ mixture: (a) before heat treatment; (b) after heat treatment at $453 \mathrm{~K}$; (c) after heat treatment at $523 \mathrm{~K}$; and (d) after heat treatment at $593 \mathrm{~K}$, respectively. Each heat treatment was carried out $<10 \mathrm{MPa}$ of hydrogen. temperature $>523 \mathrm{~K}$. The reason for the absence of a diffraction pattern for $\mathrm{Mg}\left(\mathrm{BH}_{4}\right)_{2}$ may be that the compound synthesized by this method does not crystallized sufficiently. Orimo et al. [15] have reported that long-range order of $\mathrm{LiBH}_{4}$ disappears when $\mathrm{LiBH}_{4}$ melts and solidifies again. The same phenomena may happen in the sample after heat treatment.

TPD measurement of the $\mathrm{LiBH}_{4}$ and $\mathrm{MgCl}_{2}$ mixture was carried out after heat treatment at $593 \mathrm{~K}$ for $3 \mathrm{~h}<10 \mathrm{MPa}$ of hydrogen. After heat treatment, the sample was cooled down to room temperature $<10 \mathrm{MPa}$ of hydrogen. Subsequently, hydrogen gas was extracted from the cylinder to vacuum at room temperature, where no gas evolution was observed from the sample during this procedure. After evacuation, the sample was heated with a heating rate of $0.2 \mathrm{~K} / \mathrm{min}$. The thermograms of the TPD measurement are shown in Fig. 4. The hydrogen desorption temperature of the sample after the heat treatment is approximately $100 \mathrm{~K}$ lower as compared to that of the pure $\mathrm{LiBH}_{4}$ sample. The sample after heat treatment has two desorption peaks. It starts to decompose at $500 \mathrm{~K}$ and the 1 st desorption peak appears around $563 \mathrm{~K}$. This peak is dominant and more than half of hydrogen is evolved. The second desorption peak starts at $600 \mathrm{~K}$ and it is very sharp as compared to the 1st desorption peak. The shape of two independent desorption peaks implies that decomposition reaction consists of two steps.

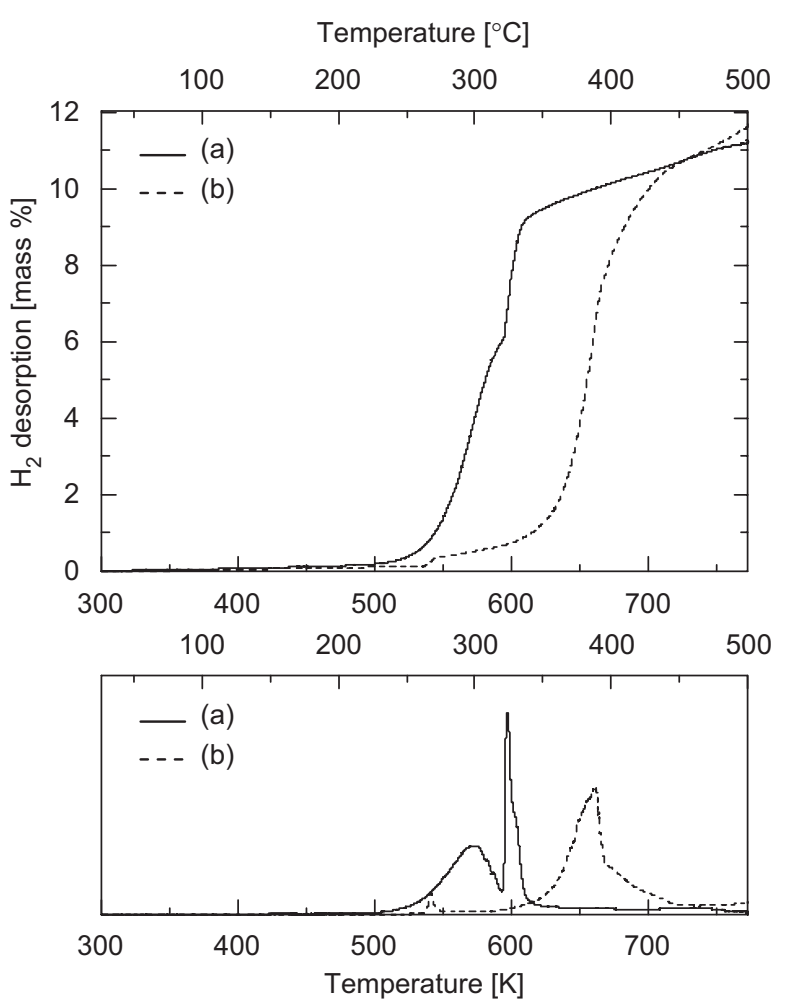

Fig. 4. Temperature-programmed desorption spectra of: (a) $\mathrm{LiBH}_{4}$ and $\mathrm{MgCl}_{2}$ mixture after heat treatment at $593 \mathrm{~K}<10 \mathrm{MPa}$ of hydrogen; and (b) pure $\mathrm{LiBH}_{4}$. The samples were heated after evacuation at room temperature with a heating rate of $0.2 \mathrm{~K} / \mathrm{min}$. 


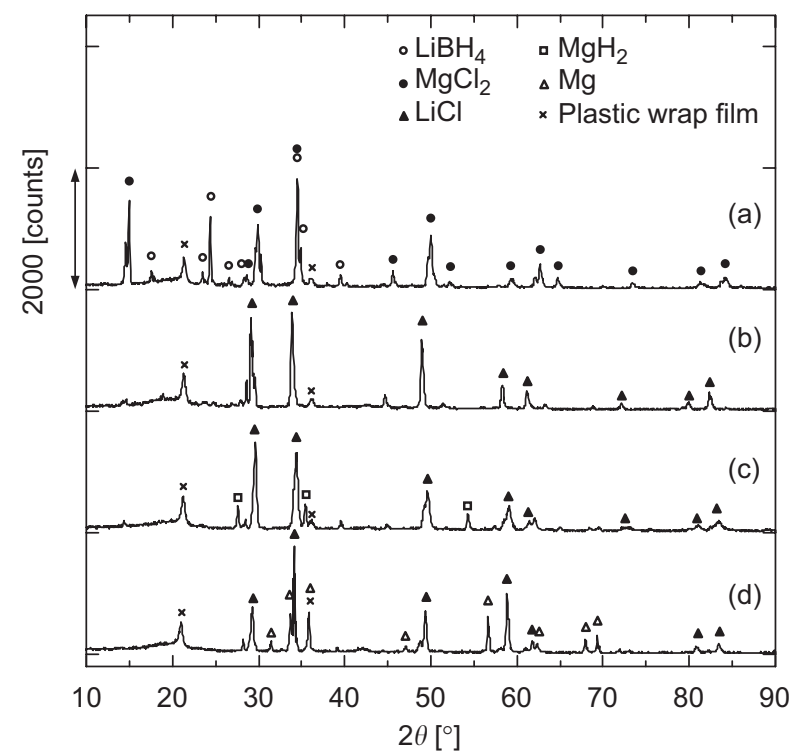

Fig. 5. Powder X-ray diffraction profiles of $\mathrm{LiBH}_{4}$ and $\mathrm{MgCl}_{2}$ mixture: (a) before heat treatment; (b) after heat treatment at $593 \mathrm{~K}<10 \mathrm{MPa}$ of hydrogen; (c) after desorption up to 593K; and (d) after desorption up to $773 \mathrm{~K}$ in vacuum, respectively.

Fig. 5 shows the XRD measurement results of the $\mathrm{LiBH}_{4}$ and $\mathrm{MgCl}_{2}$ mixture (a) before heat treatment, (b) after heat treatment at $593 \mathrm{~K}$ for $3 \mathrm{~h}$, (c) after TPD measurement up to $593 \mathrm{~K}$ and (d) after TPD measurement up to $773 \mathrm{~K}$. As it is shown in Fig. 5(c), after the desorption measurement up to $593 \mathrm{~K}$, the peaks which correspond to $\mathrm{MgH}_{2}$ are observed, whereas the diffraction pattern of metallic $\mathrm{Mg}$ is not observed. On the other hand, as is shown in Fig. 5(d), after heated up to $773 \mathrm{~K}$, the peaks corresponding to $\mathrm{Mg}$ are clearly present, where the peaks from $\mathrm{MgH}_{2}$ are no longer observed. This result supports the following twostep reaction:

$\mathrm{Mg}\left(\mathrm{BH}_{4}\right)_{2} \rightarrow \mathrm{MgH}_{2}+2 \mathrm{~B}+3 \mathrm{H}_{2} \quad$ (1st step),

$\mathrm{MgH}_{2} \rightarrow \mathrm{Mg}+\mathrm{H}_{2} \quad$ (2nd step).

\section{Conclusions}

We intended to synthesize $\operatorname{Mg}\left(\mathrm{BH}_{4}\right)_{2}$ by decomposition reaction of $\mathrm{LiBH}_{4}$ with $\mathrm{MgCl}_{2}$ by heat treatment without using a solvent, where the product consists of $\mathrm{LiCl}$ and a compound of magnesium, boron and hydrogen. Hydrogen desorption property of the product was examined by TPD measurement. It was found that the decomposition temperature of the product is approximately $100 \mathrm{~K}$ lower than that of $\mathrm{LiBH}_{4}$ and the decomposition consists of a two-step reaction. The 1st decomposition peak is dominant and is around $563 \mathrm{~K}$. The 2 nd decomposition reaction occurs at the temperature $>590 \mathrm{~K}$. The products of the $1 \mathrm{st}$ and 2nd decomposition reaction are $\mathrm{MgH}_{2}$ and $\mathrm{Mg}$, respectively. Therefore, this is an evidence for $\mathrm{Mg}\left(\mathrm{BH}_{4}\right)_{2}$ as the possible reaction product, although no diffraction pattern was found.

\section{Acknowledgments}

This study was partially supported by the New Energy and Industrial Technology Development Organization (NEDO), International Joint Research under the "Development for Safe Utilization and Infrastructure of hydrogen" Project (2005-2006) and the Swiss Federal Office of Energy (BFE) project "Hydrogen storage in metal- and complex hydrides", No. 100324 (2003-2006).

\section{References}

[1] Züttel A. Materialstoday 2003:24.

[2] Bogdanovic BM, Schwickardi J. J Alloys Compds 1997;253-254:1.

[3] Züttel A, Rentsch S, Fischer P, Wenger P, Sudan P, Mauron Ph, et al. J Alloys Compds 2003;356:515.

[4] Chen P, Xiong Z, Luo J, Lin J, Tan KL. Nature 2002;420:302.

[5] Vajo JJ, Skeith SL, Mertens F. J Phys Chem B 2005;109(9):3719.

[6] Orimo S, Nakamori Y, Züttel A. Mater Sci Eng B 2004;108:51.

[7] Nakamori Y, Orimo S. J Alloys Compds 2004;370:271.

[8] Nakamori Y, Miwa K, Ninomiya A, Li H, Ohba N, Towata S, Zuttel A, Orimo S. Communicated.

[9] Miwa K, Ohba N, Towata S, Nakamori Y, Orimo S. J Alloys Compds 2005;404-406:140.

[10] Yoshino M, Komiya K, Takahashi Y, Shinzato Y, Yukawa H, Morinaga M. J Alloys Compds 2005;404-406:185.

[11] Plesek J, Hermanek S. Collect Czech Chem Commun 1966;31:3845.

[12] Konoplev VN. Russ J Inorg Chem 1980;25(7):964.

[13] Konoplev VN, Silina TA. Russ J Inorg Chem 1974;19(9):1383.

[14] Stasinevich DS, Egorenko GA. Russ J Inorg Chem 1968;13(3):341.

[15] Orimo S, Nakamori Y, Kitahara G, Miwa K, Ohba N, Towata S, et al. J Alloys Compds 2005;404-406:427-30. 